\title{
Peningkatan Kompetensi Guru Melalui Pelatihan Keterampilan Pembuatan E-Presentation
}

\author{
Oman Somantri $^{1 *}$, Taufiq Abidin², Sena Wijayanto², Dega Surono Wibowo² dan Dairoh² \\ ${ }^{1}$ Politeknik Negeri Cilacap, Jl. Dr. Soetomo No.01 Karangcengis Sidakaya Cilacap, Indonesia \\ ${ }^{2}$ Politeknik Harapan Bersama Tegal, Jln. Mataram No.09 Pesurungan Lor Kota Tegal, Indonesia \\ *Email korespondensi: oman_mantri@yahoo.com
}

\begin{abstract}
Abstrak
Electronic presentations merupakan sebuah media presentasi yang dibuat dengan menggunakan berbagai macam tools seperti powerpoint, prezi dan lain sebagainya yang berguna untuk mempresentasikan kepada khalayak dari berbagai macam bidang baik itu bisnis, perkantoran maupun pendidikan. SMK Pusponegoro saat ini mempunyai kesulitan didalam mencari media pembelajaran yang sesuai dengan keadaan sekarang yang tujuannya ingin meningkatkan pola sistem pembelajaran di sekolah tersebut, maka dalam hal ini pembuatan elektronic presentation disepakati untuk diberikan melalui kegiatan pelatihan. Tujuan dari kegiatan yang dilaksanakan adalah sebagai upaya untuk meningkatkan keterampilan guru SMK Pusponegoro Berbes dalam pembuatan e-presentation. Metode kegiatan yang digunakan untuk mencapai tujuan dari kegiatan pengabdian masyarakat ini adalah dengan metode ceramah dan praktek dengan menggunakan media powerpoint dan Prezi, dimana semua peserta pelatihan setelah mendapatkan materi yang disampaikan kemudian mempraktekan apa yang sudah diberikan implementasinya. Hasil kegiatan pada pelaksanaan pelatihan ini adalah bertambahnya ilmu pengetahuan dan keterampilan serta pemahaman akan penerapan penggunaan electronic presentation yang diberikan kepada para Guru SMK Pusponegoro Jatibarang Brebes yang ikut pelatihan tersebut. Berdasarkan kegiatan yang telah dilaksanakan, tersebut dapat memberikan pemahaman baru mengenai terdapatnya penggunaan media pembelajaran alternatif yang bisa digunakan dalam proses pembelajaran di kelas.
\end{abstract}

Kata kunci: Electronic Presentation, Guru, Media Pembelajaran

\begin{abstract}
Electronic presentations are media presentations made using various tools, such as Powerpoint, prezy and others that are useful for presenting to audiences from various fields, whether it is business, offices or education. Pusponegoro Vocational School recently face difficulties in finding appropriate media that can improve the pattern of the distribution system in the school, therefore the electronic manufacturing presentation is introduced through training activities. The objective of the activity is to enhance Pusponegoro Vocational School teachers' ability to make e-presentation. The methods used to achieve the objectives of this community service activity are the lecture method and practice using Powerpoint and Prezi media, in which all the training participants applied the presented materials into practice. The result of the activity is the teachers' broader knowledge, skill and understanding of the application of e-presentation. Based on the results of community service activities, it can be concluded that the knowledge and understanding of the application of electronic presentations given to the Pusponegoro Jatibarang Vocational School Teachers can provide new insights into the use of alternative learning media that can be beneficial in the learning process.
\end{abstract}

Keywords: Electronic Presentation, Teacher, Learning Media

Format Sitasi: Somantri, O., Abidin, T., Wijayanto, S., Wibowo, D.S., dan Dairoh. (2019) Peningkatan Kompetensi Guru Melalui Pelatihan Keterampilan Pembuatan E-Presentation. Jurnal Solma, 8(2): 219-228. Doi: https://dx.doi.org/10.29405/solma.v8i2.3245

Diterima: 03 Maret 2019 | Revisi: 24 September 2019 | Dipublikasikan: 21 Oktober 2019 
(C) 2019. Oleh authors. Lisensi Jurnal Solma, LPPM-Uhamka, Jakarta. Artikel ini bersifat open access yang didistribusikan di bawah syarat dan ketentuan Creative Commons Attribution (CC-BY) license. (http://creativecommons.org/licenses/by/4.0/).

\section{PENDAHULUAN}

Kemampuan dalam mengajar dan mempresentasikan ilmu yng disampaikan oleh Guru kepada siswanya menjadi salah satu tolak ukur keberhasilan dari keberhasilan sebuah pembelajaran untuk menghasilkan outpout luaran siswa yang diinginkan nantinya. Salah satu media yang saat ini sering digunakan adalah dalam bentuk electronic presentation. EPresentation sebagai salah satu implementasi penerapan teknologi yang berkembang saat ini, memberikan sebuah kemudahan efektifitas pada aktifitas proses pembelajaran. Konsep dari model ini adalah dimana guru dan siswa dapat memanfaatkan teknologi yang ada tanpa melihat dimanapun mereka berada dengan kata lain tidak mesti dilakukan secara tatap muka.

Sebuah sekolah yang siap menghadapi tantangan baik itu dari sisi akademik, keilmuan maupun sumber daya manusia sangat penting saat ini. Perkembangan teknologi yang semakin berkembang dan saat ini menjadi sebuah kebutuhan menjadikan sekolah harus siap menghadapi segala apapun yang terjadi, termasuk pola pembelajaran yang dilakukan oleh sekolah-sekolah terhadap siswa-siswinya. Sampai saat ini terkadang masih terdapat guru dan pendidik yang masih memandang bahwa pemanfaatan teknologi informasi tidak dijadikan sebagai prioritas dalam upaya meningkatkan keterampilan penguasaan teknologi tersebut (Husain, 2014). Perkembangan ilmu pengetahuan saat ini memungkinkan untuk membuat sebuah media pembelajaran yang interaktif (Andrizal \& Arif, 2017; Nurseto, 2011; Putra \& Nugroho, 2016; Sukoco, Arifin, Sutiman, \& Wakid, 2014).

E-Presentation adalah sebuah media alat bantu untuk mempresentasikan gagasan atau pemikiran kepada orang lain dengaan mengkombinaksikan internet sebagai media dalam penyampaiannya. Electronic presentation merupakan sebuah metode yang digunakan untuk presentasi kepada khalayak baik itu dalam bidang bisnis, pemerintahan, ataupun dalam bidang pendidikan (Shallcross \& Harrison, 2007). Pembangunan e-presentation dalam pembuatannya menggunakan berbagai macam software seperti powerpoint, freelance, corel presentation, astound, prezi, sliderockect marketing, dan lain sebagainya.

Media pembelajaran yang sering digunakan selama ini adalah dengan penggunaan powerpoint sebagai media, dengan kelebihan yang dimilikinya powerpoint berdasarkan beberapa penelitian memperlihatkan bahwa media tersebut dapat memberikan peningkatan prestasi siswa karena tingkat pemahaman materi yang disampaikan oleh instruktur atau guru 
dapat lebih dipahami oleh siswa (Ainin, Ahsanuddin, \& Asrori, 2018; Ayuningtyas, H., Pujiastuti, Retnowati, \& Indrianingsih, 2018; Craig \& Amernic, 2006; Husain, 2014). Saat ini banyak para insturktur mengadopsi powerpoint untuk pengajaran di kelas karena efektivitas instruksinya, selain itu powerpoint memungkinkan instruktur untuk menghabiskan waktu tambahan pada konten pengajaran yang ditampilkan pada slide dan interaksi belajar siswa dengan menghindari penulisan materi yang disampaikan secara panjang lebar di papan tulis (Uz, Orhan, \& Bilgiç, 2010). Akan tetapi disisi lain terdapat beberapa kelemahan yang dimiliki oleh power point dimana salah satunya adalah selain bersifat offline dan fasilitas tampilan yang terbatas juga tidak bisa diakses secara online dimanapun siswa dan guru berada sehingga sedikit menyulitkan dalam pencarian materi.

Aplikasi electronic presentation lain yang sering digunakan adalah Prezi, aplikasi cloud computing yang diluncurkan pda tahun 2009 ini dianggap sebagai freeware inovatif karena berpotensi akan menggantikan powerpoint (Chou, Chang, \& Lu, 2015; Strasser, 2014). Kelebihan yang dimiliki Prezi adalah selain fitur kanvas yang tidak terbatas dan memiliki gaya presentasi yang nonlinier, juga memberikan kesempatan kepada user pengguna untuk dapat mengedit slide secara online (Perron \& Stearns, 2011)

Upaya yang dilakukan oleh beberapa pihak lain untuk meningkatkan keterampilan dan kompetensi guru khususnya dalam membuat media ajar sebagai alat untuk presentasi sebelumnya telah banyak dilakukan dengan berbagai macam metode dan tujuan yang telah ditentukan. Pengembangan media pembelajaran berbasis multimedia untuk meningkatkan kualitas dan kreatifitas guru dalam mempresentasikan konten isi materi yang disampaikan dilakukan oleh (Riskiawan, Setyohadi, \& Arifianto, 2016), kegiatan ini dilakukan di SMA Al-Hidayah Jember dengan tujuan guru mampu menguasi aplikasi khususnya multimedia dan pengembangan media pembelajaran. Upaya dalam meningkatkan efektivitas serta efisiensi proses pembelajaran dilakukan juga oleh (Husain, 2014) di SMA Muhammadiyah Tarakan, dimana kegiatan yang dilakukan ini untuk mengoptimalkan pemanfaatan media pembelajaran berjejaring internet karena saat ini masih menggunakan powerpoint. Selain itu pemanfatan Edmodo sebagai media pembelajaran dan presentasi isi konten dilakukan juga sebagai upaya peningkatan kemampuan guru dalam meningkatkan prestasi siswa (Somantri, Abidin, Wibowo, \& Wiyono, 2017). Selain itu beberapa tools aplikasi seperti office mix, onenote, dan sway diberikan juga dalam pelatihan kepada para Guru oleh (Usodo, Kurniawati, \& Kuswardi, 2016) untuk membuat media pembelajaran bagi guru-guru 
Matematika di SMA Kabupaten Sragen untuk mengoptimalkan proses pembelajaran di kelas termasuk salah satunya presentasi isi konten materi pelajaran yang disampaikan.

SMK Puponegoro Jatibarang Brebes merupakan sekolah menengah kejuruan swasta di Kabupaten Brebes yang berada di wilayah terletak di wilayah Jatibarang Kabupaten Brebes jawa tengah. Sekolah tersebut saat ini mempunyai jumlah pengajar guru sebanyak 19 guru dan siswa aktif yang belajar adalah 251 orang siswa dari berbagai jurusan yang ada disana seperti jurusan teknologi jaringan komputer, akuntansi dan otomotif.
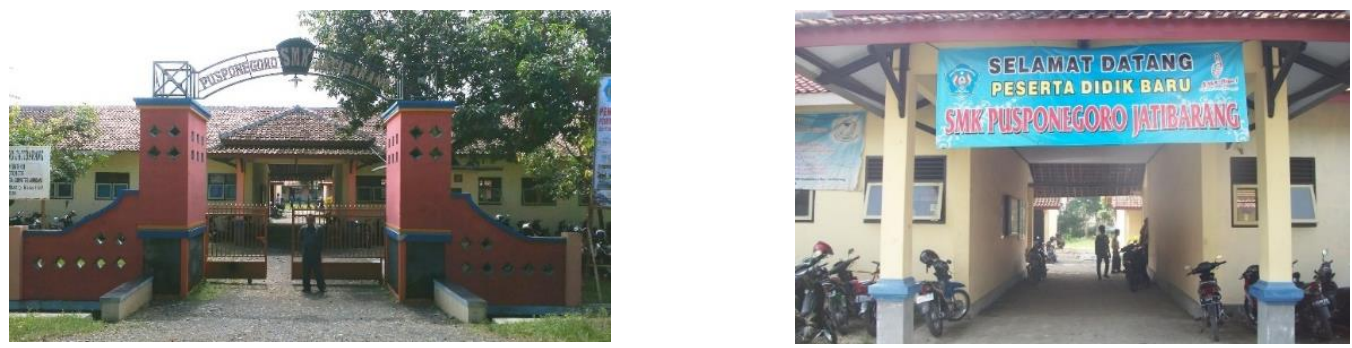

Gambar 1. Situasi dan kondisi sekolah SMK Pusponegoro Jatibarang, (a) tampak suasana gerbang depan sekolah, (b) suasana lingkungan dalam sekolah.

Optimalisasi pola pembelajaran dan pengajaran terhadap siswa pada sekolah SMK Puponegoro menjadi prioritas, hal ini dilakukan untuk meningkatkan kualitas luaran output siswa yang dihasilkan. Berdasarkan data yang ada, terkait dengan jumlah pengajar yang sudah cukup banyak dan ideal sesuai dengan rasio sudah tentu hal ini menjadikan sekolah tersebut perlu adanya sebuah pembinaan yang berkelanjutan khususnya kualitas guru pada pola proses pembelajaran yakni salah satunya adanya proses pola penyampaian materi pelajaran dengan cara optimalisasi teknik presentasi guru yang sesuai dengan yang diharapkan sehingga siswa dapat lebih mudah dalam menerima materi pelajaran ynag disampaikan.

Tujuan dari kegiatan pengabdian ini adalah memberikan pelatihan pembuatan dan optimalisasi e-presentation yang berbasiskan teknologi informasi sebaia salah satu media pembelajaran yang dapat digunakan oleh pendidik yang berada di SMK Pusponegoro Jatibarang Brebes sehingga dapat meningkatkan kemampuan dan keterampilan pendidik dalam mempresentasikan materi pelajaran yang disampaikan serta dapat meningkatkan pemahaman siswa dalam menerima materi yang disampaikan Guru dengan harapan adanya peningkatan prestasi siswa. 


\section{MASALAH}

Infrastruktur teknologi informasi yang terdapat di SMK Pusponegoro Jatibarang Brebes saat ini cukup baik dan memadai, ini terbukti dari beberapa ruang kelas yang telah sesuai dengan standar, terdapatnya laboratorium komputer, dan perpustakaan serta akses internet yang difasilitasi oleh sekolah. Saat ini proses pembelajaran yang dilakukan oleh guru dan pengajar di sekolah tersebut sesuai dengan hasil evaluasi masih banyak terdapat yang menggunakan metode konvensional dan belum semuanya memanfaatkan media teknologi informasi sebagai alat bantu dalam pembelajaran tersebut sehingga hal memberikan sedikit kendala dalam proses penyampaian materi yang diberikan kepada siswa karena harus menggunakan tulisan di papan tulis serta buku-buku. Bertolak pada keadaan tersebut perlu kiranya ada sebuah upaya dalam peningkatan keterampilan guru dalam membuat dan menggunakan electronic presentation sehingga kompetensi yang diharapkan baik itu guru maupun siswa dapat tercapai dan adanya efektivitas dalam proses pembelajaran sekolah.

Berdasarkan kesepakatan bersama dengan mitra dalam hal ini sekolah SMK Pusponegoro Jatibarang Brebes maka dilakukan upaya-upaya dan salah satu prioritas upaya tersebut adalah melakukan kegiatan pelatihan keterampilan guru dalam membuat epresentation dengan menggunakan tools aplikasi powerpoint dan prezi. Kegiatan yang dilakukan sebagai upaya dalama menjawab bagaiamana kebermafaatan penerapan $e$ presentation sebagai salah satu alternatif dalam membantu sebuah proses pembelajaran di tingkat satuan pendidikan. Selain itu kegiatan ini dilakukan sebagai upaya menjawab bagaimana memaksimalkan kemampuan para pendidik di SMA Puponegoro Jatibarang dalam memanfaatkan teknologi informasi sehingga dapat mengembangkan potensi dari sekolah serta dapat meningkatkan pengetahun dan keterampilan pendidik dalam membuat e-presentation sehingga terampil dalam menggunakannya.

\section{METODE PELAKSANAAN}

Metode yang digunakan dalam kegiatan ini adalah pelatihan, dimana pada metode ini untuk mencapai tujuan yang diharapkan pada proses pelaksanaannya mengggunakan metode model pendekatan partisipatif dimana pada kegiatan ini para peserta pelatihan berperan aktif dalam proses pembelajaran, dikarenakan peserta pelatihan adalah terdiri dari para orang dewasa maka kesesuaian metode yang digunakan diperhatikan pula demi mencapai tujuan target yang telah ditentukan yaitu adanya peningkatan pemahaman dan keterampilan dalam 
pembuatan e-presentation yang baik. Metode pembelajaran menggunakan konsel learning by doing, artinya selain ceramah dan diskusi kegiatan praktek menjadi prioritas selain itu metode pendampingan dilakukan selama kegiatan berlangsung dan pasca kegiatan.

Kegiatan pengabdian sebelum pelaksanaan dilakukan pengumpulan data terlebih dahulu untuk menunjang kegiatan baik pada saat pra-kegiatan, pelaksanaan kegiatan maupun pasca kegiatan pelatihan. Teknik pengumpulan data dilakukan dengan melakukan observasi ke tempat pelaksanaan kegiatan serta melakukan wawancara dengan mitra sehingga diperoleh kesepakatan langkah-langkah dalam mengatasi permasalahan-permasalahan yang ada dan menghasilkan upaya skala prioritas yang dilakukan. Setiap data yang telah didapatkan kemudian dianalisis untuk nantinya disimpulkan terkait dengan kegiatan yang dilakukan, pada tahapan analisis data ini dilakukan secara kualitatif.

Pelaksanaan kegiatan pengabdian pelatihan dilakukan di kampus SMK Pusponegoro Jatibarang Tegal yang beralamat di Jalan Pramuka No.85 Jatibarang Kabupaten Brebes Jawa Tengah. Kegiatan dilakukan selama dua hari pada tanggal 29 s.d 30 Januari 2019. Peserta pelatihan adalah terdiri dari para guru dan staf pengajar SMK Puponegoro Jatobarang Brebes yang berasal dari berbagai jurusan sebanyk 19 orang peserta kegiatan.

\section{HASIL DAN PEMBAHASAN}

Sesuai dengan perencanaan yang telah ditentukan, pelaksanaan kegiatan pelatihan dilaksanakan berdasarkan kesepakatan bersama antara tim PKM dengan Mitra. Kegitan pelatihan diberikan dalam upaya untuk meningkatkan kemampuan keterampilan para Guru di SMK Pusponegoro Jatibarang Brebes dalam membuat elektronik presentation yang akan digunakan sebagai media pembelajaran untuk meningkatkan prestasi siswa khususnya dalam pola penerimaan materi yang disampaikan. Media pembelajaran yang akan digunakan terdiri dari dua tools software, yaitu Powerpoint dan Prezi.

\section{Pra-Kegiatan Pelatihan}

Persiapan dilakukan dengan terlebih dahulu menyiapkan segala sesuatu hal yang terkait dengan pelaksanaan kegiatan, mulai dari setting tempat kegiatan, jaringan internet, modul pelatihan, dan hal teknis lainnya yang harus dipersiapkan. Pada tahapan ini pula sebelum pelatihan dimulai dilakukan proses assessment peserta pelatihan. Assessment dilakukan untuk menilai peserta pelatihan yang akan mengikuti kegiatan tersebut sehingga tim instruktur pelatihan dapat mengukur sejauhmana kemampuan peserta pelatihan sehingga 
model atau pola pelatihan yang diberikan sesuai dengan tujuan outcome yang diharapkan, terdiri dari jumlah peserta yang ikut pelatihan, pendidikan peserta serta usia peserta pelatihan seperti yang diperlihatkan pada Tabel 1. dan Gambar 2. Berdasarkan data yang telah diperoleh maka diperoleh gambaran mengenai model dan metode pembelajaran yang sesuai dengan kondisi peserta serta kondisi tempat kegiatan pelatihan.

Tabel 1. Data Identitas Peserta Pelatihan beradasarkan usia

\begin{tabular}{cc}
\hline Umur (Tahun) & Jumlah \\
\hline$>30$ & 3 \\
$31-35$ & 5 \\
$36-40$ & 2 \\
$41-45$ & 0 \\
$46-50$ & 2 \\
$51-55$ & 4 \\
$>55$ & 3 \\
Total & 19
\end{tabular}

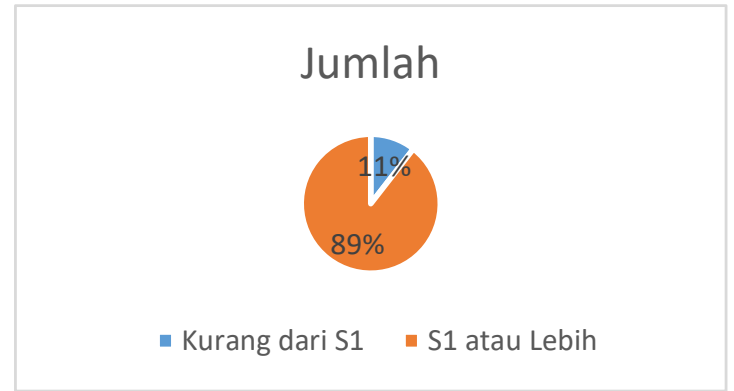

Gambar 2. Persentasi keadaan peserta pelatihan berdasarkan pendidikan

\section{Pelaksanaan kegiatan}

Dalam upaya memenuhi tuntutan hasil kegiatan yang diinginkan, pada kegiatan ini pendampingan dilakukan selain oleh tim pelaksana PKM, kegiatan ini juga melibatkan beberapa mahasiswa yang diikutkan untuk membantu dalam pendampingan peserta pelatihan sehingga pelaksanaan pelatihan dapat lebih optimal. Selama kegiatan berlangsung terdapat dua materi utama yang diberikan kepada para peserta pelatihan yaitu mengenai optimalisasi pengembangan power point sebagai media presentasi, dan materi pembuatan media presentasi menggunakan Prezi.
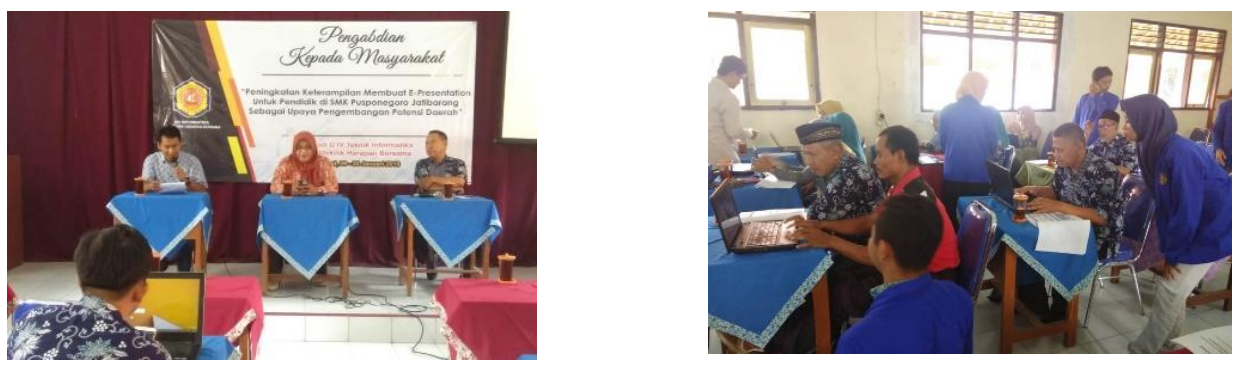

Gambar 3. Pemberian materi pelatihan pembuatan media pembelajaran dengan electronic presentation 
Berdasarkan pada pelaksanaan kegiatan pelatihan yang telah dilaksanakan menghasilkan beberapa hasil yang didapatkan, diantaranya yaitu:

1. Pemberian materi melatihan yang diberikan kepada guru SMK Pusponegoro Jatbarang Brebes diterima dengan respon yang positif oleh para peserta kegiatan, disamping itu penggunaan media yang dianggap masih baru oleh para peserta memberikan daya tarik tertentu bagi peserta sehingga banyak diantara para peserta pelatihan yang tertarik khususnya pada materi aplikasi Prezi secara online.

2. Peserta pelatihan dapat mampu membuat media presentasi elektronik dengan menggunakan powerpoint dan aplikasi Prezi dengan baik, hal ini terlihat hampir semua peserta pelatihan dapat menyelesaikan setiap arahan yang diberikan oleh instruktur.

3. Adanya ketertarikan dan keinginan dari guru-guru dan pengajar SMK Pusponegoro Jatibarang untuk dapat mengimplementasikan hasil dari program pelatihan yang telah dilaksanakan.

\section{Evaluasi Pelatihan}

Sesuai dengan perencanaan yang telah ditentukan maka untuk dapat mengevalusi keberhasilan dari pelatihan yng telak dilaksanakan terhadap materi yang diberikan, maka dilakukan evaluasi terhadap peserta pelatihan yaitu berupa penugasan pembuatan media pembelajaran menggunakan electronic presentation untuk mengukur sejauhmana tingkat keberhasilan dari pelatihan yang dilaksanakan. Selain itu evaluasi dilakukan juga dengan menggunkan metode umpan balik terhadap pelaksanaan kegiatan tersebut, sehingga didapatkan sebuah hasil mengenai efektifitas kegiatan yng dilaksanakan serta mendapatkan gambaran terhadap pelaksanaan kegiatan kedepannya. Berdasarkan hasil evaluasi terlihat bahwa $75 \%$ peserta pelatihan dapat menyelesaikan tugas tersebut sesuai dengan arahan, sehingga didapatkan bahwa tujuan pelatihan yang dilakukan sudah tercapai dan sesuai dengan harapan. Setelah dilakukannya evaluasi, Gambar 5 memperlihatkan contoh dari hasil pembuatan media pembelajaran dari penggunaan elektronik presentation yang digunakan oleh salah satu peserta kegiatan pelatihan.

\section{KESIMPULAN}

Kegiatan pengabdian berupa pelatihan dalam membuat media presentasi sebagai media pembelajaran dengan memanfaatkn electronic presentation pada guru-guru SMK Pusponegoro Jatibarang Brebes menghasilkan beberapa kesimpulan yaitu pemahaman akan 
penerapan teknologi informasi melalui aplikasi komputer dan internet yang diberikan kepada para Guru SMK Puponegoro Jatibarang Brebes telah memberikan sebuah pemahaman baru mengenai terdapatnya media pembelajaran alternative sebagai media presentasi yang dapat digunakan dalam proses pembelajaran di kelas sehingga saat ini sekolah tersebut akhirnya mempunyai konsep metode pembelajaran baru yang dapat digunakan oleh guru pada proses pembelajaran.

Mengingat besarnya manfaat dari kegiatan pelatihan ini maka disarankan untuk dapat dipertimbangkan yaitu adanya pelatihan berkelanjutan dan pendampingan sehingga dapat lebih memperdalam kembali materi yang disampaikan, serta adanya monitoring dan evaluasi terhadap pembuatan e-presentation yang sudah diberikan sehingga dapat engukut sejauhmana keberhasilan dari pelatihan yang diberikan kepada peserta pelatihan.

\section{UCAPAN TERIMA KASIH}

Terimakasih kami sampaikan kepada SMK Pusponegoro Jatibarang Brebes sebagai mitra kegiatan, dan P3M Politeknik Harapan Bersama Tegal yang telah memberikan hibah pendanaan kegiatan PKM ini di tahun anggaran 2019, serta dukungan moril dari P3M Politeknik Negeri Cilacap,

\section{DAFTAR PUSTAKA}

Ainin, M., Ahsanuddin, M., \& Asrori, I. (2018). Pelatihan Powerpoint Bagi Guru Bahasa Arab MTs Kota dan Kabupaten Kediri. 1(1), 74-79.

Andrizal, \& Arif, A. (2017). Pengembangan Media Pembelajaran Interaktif Pada Sistem ELearning Universitas Negeri Padang. 17(2), 1-10.

Ayuningtyas, A., H., A. S., Pujiastuti, A., Retnowati, N. D., \& Indrianingsih, Y. (2018). Pendampingan Pembuatan Bahan Ajar Bagi Guru Sekolah Dasar Islam Terpadu ( SDIT ) Salsabila Al Muthi' in Berbasis Multimedia dengan Menggunakan Microsoft Power Point. Jurnal Pengabdian Masyarakat Bidang Teknologi, 1(No. 1), 1-6.

Chou, P.-N., Chang, C.-C., \& Lu, P.-F. (2015). Prezi versus PowerPoint: The effects of varied digital presentation tools on students' learning performance. Computers \& Education, 91, 73-82. https://doi.org/10.1016/j.compedu.2015.10.020

Craig, R. J., \& Amernic, J. H. (2006). PowerPoint presentation technology and the dynamics of teaching. Innovative Higher Education, 31(3), 147-160. https://doi.org/10.1007/s10755-006-9017-5

Husain, C. (2014). Pemanfaatan Teknologi Informasi dan Komunikasi dalam Pembelajaran di SMA Muhammadiyah Tarakan. Jurnal Kebijakan Dan Pengembangan Pendidikan, 2(2), 184-192. 
Nurseto, T. (2011). Membuat Media Pembelajaran yang Menarik. Jurnal Ekonomi Dan Pendidikan, 8, 19-35.

Perron, B. E., \& Stearns, A. G. (2011). A Review of a Presentation Technology: Prezi. Research on Social Work Practice, 21(3), 376-377. https://doi.org/10.1177/1049731510390700

Putra, D. R., \& Nugroho, M. A. (2016). Pengembangan media pembelajaran berbasis komputer dengan. Pengembangan Game Edukatif Berbasis Android Sebagai Media Pembelajaran Akuntansi Pada Materi Jurnal Penyesuaian Perusahan Jasa, XIV No.1(3), 25-34.

Riskiawan, H. Y., Setyohadi, D. P. S., \& Arifianto, A. S. (2016). Pelatihan Pengembangan Media Pembelajaran Berbasis Multimedia Untuk Meningkatkan Kualitas Dan Kreativitas Guru SMA. Jurnal Pengabdian Masyarakat J-DINAMIKA, 1(1), 48-52.

Shallcross, D. E., \& Harrison, T. G. (2007). Lectures: electronic presentations versus chalk and talk - a chemist's view. Chem. Educ. Res. Pract., 8(1), 73-79. https://doi.org/10.1039/B6RP90021F

Somantri, O., Abidin, T., Wibowo, D. S., \& Wiyono, S. (2017). Peningkatan Kemampuan Guru Dalam Membuat E - Learning Sebagai Media Pembelajaran Berbasis Teknologi Informasi Di Sma Negeri 1 Subah. Jurnal Pengabdian Kepada Masyarakat (JPKM), 23(2), 332-337.

Strasser, N. (2014). Using Prezi In Higher Education. Journal of College Teaching \& Learning (TLC), 11(2), 95. https://doi.org/10.19030/tlc.v11i2.8547

Sukoco, Arifin, Z., Sutiman, \& Wakid, M. (2014). Pengembangan Media Pembelajaran Interaktif Berbasis Komputer Untuk Peserta Didik Mata Pelajaran Teknik Kendaraan Ringan. Jurnal Pendidikan Teknologi Dan Kejuruan, 22(2), 215-226.

Usodo, B., Kurniawati, I., \& Kuswardi, Y. (2016). Pelatihan Penerapan Beberapa Aplikasi Dari Microsoft: Office Mix , Onenote, Sway Dalam Pembelajaran Bagi Guru-Guru Matematika. Jurnal Elektronik Pembelajaran Matematika, 4(9), 743-752.

Uz, Ç., Orhan, F., \& Bilgiç, G. (2010). Prospective teachers' opinions on the value of PowerPoint presentations in lecturing. Procedia - Social and Behavioral Sciences, 2(2), 2051-2059. https://doi.org/10.1016/j.sbspro.2010.03.280 